\title{
THE DILEMMA OF SOMALI REFUGEES
}

Bishara H. Ali, M.A., M.S.W.

President, The Ottawa-Carleton Somali Community

The first Somall refugee family arrived in the capital in the fall of $\mathbf{1 9 8 6}$ Since then, the Somall community in the Ottawa-Carleton region has grown to 3,500 members. Although the agony of the Somall refugees has, continued for a decade, only recently has their plight come to the attention of the International and Canadian media after they have crashed on our doors and those of Western Burope.

Somalia is a country of 6.5 million people. Located unfortunately in the Horn of Africa with traditional enemies as neighbours - Ethiopla and Kenya, it is one of the poorest nations in the world. It is run by a tyrannical dictator - Gen. Mohamed Siad Barre and his family that participated in the mass murder, imprisonment, arrest and subsequent disappearance of thousands of political opponents since 1977. Less that one per cent of the population owns 54 per cent of the national wealth; eighty per cent of the gross national product goes to the five per cent of the population who hold power. The averageincomein Somaligis $\$ 10$ per month; 87 percent of the population are unemployed waiting for things to happen.

Life expectancy is 40 years, there is a high death rate due to malnutrition, tuberculosis, food poisoning, aided by political and tribal terrorism of the secret police. Ninety per cent of the Heads of Families are women who are left with maintenanceand support of their families since men are either in prison, at war, or have become refugees in such places as Conada.

Political violence and genocide against the opponents of the president have been the norm since 1977. The president's son and wife alone are responsible for the deaths of over 38,000 political and religious dissidents. They have hired and recruited special brigades (Red Berets) from their own clansin order to keep the power and security of the nation in a firm hand.

This and other national crises in Somalia has created mass migration out of the country to Europe and North America. Lately, this migration has been so great that it is viewed as one of the tragic phenomena in the history of Somalia. An estimated one-fifth of the populationhasleft the country as refugees to Europe, Africa (Ethiopia and Kenya), U.S.A. and Canada.

The experience of Somall refugees in Canada and the Ottawa-Carleton region has not been easy. They have cultural, educational, language and physical barriers. They lack the organizational skills, and political experience and support of other immigrants who have come here before them.

The Ottawa-Carleton Somali Community is calling on concerned organizations and government agencies to help and open their hearts to the plight of the Somali refugees among us as well as help them in their struggie to restore democracy, peace and justice within their homeland by recognizing the liberation movements of the United Somali Congress and the Somall National Movements. $\square$

\section{CANADA'S AFRICAN PROGRAM}

The African program was instituted in 1978/79 after the Arusha conference which established that, as a matter of policy, African refugee situations should be solved in Africa.

Our program was designed to provide an option for the UN in exceptional . cases where theindividual concerned could not be adequately protected elsewhere in Africa. The program has worked well overall; since 1983, 10,117 Africans, including those determined in this country to be refugees, have been settled in Canada under our humanitarian and refugee programs. Privatesponsorships of Africans have increased over the years.

$\begin{array}{lrrr}\text { Year } & \begin{array}{r}\text { Covernment } \\ \text { Sponsorship }\end{array} & \begin{array}{r}\text { Private } \\ \text { Sponsorship }\end{array} & \text { Total } \\ 1983 & & 168 & 817 \\ 1984 & 649 & 175 & 1,903 \\ 1985 & 848 & 165 & 957 \\ 1986 & 792 & 319 & 1,163 \\ 1988 & 84 & 478 & 1,291 \\ 1988 & 813 & 874 & 1,980 \\ 1989 & 1,106 & 1.556 & 2592 \\ \text { Tetal } & 1.036 & 3,735 & 2,993\end{array}$

Most of the private-sponsorship applicants are relatives of Ethiopians now in Canada. 
Book Rovlows

\section{CLOSING THE DOORS: THE FAILUAE OF REFUGEE PROTECTION David Matas,Toronto, Summerhill Press, 1989. Reoiewed By Sheikh Azaad.}

Closing the Doors is an attempt by David Matas to look at the world refugee crisis and how Western nations are responding or not responding as is his contention, to the human dilemma which involves some twelve million people.

An accomplished lawyer by profession, Matas states that his desire was to answer the question, "why are people who faced possible death or torture back home, if their claim was rejected in Canada, given fewer procedural protections than someone questioning ... a parking ticket?"

Though be begins in the first of his five parts by looking at Canada's immigration history, which heclaims has changed from structural to systematic discrimination, he goes on to look at Canada's refugee determination system. By first examining the previous system

(He looks at) ... the conditions which are created and fostered by Western governments that discriminate against refugee claimants once they are in countries of asyluon.

prior to the passage of Bills C-55 and C84, and the system that replaced it, he points out the inadequacies and shortcomings that necessitated the creation of a new system. The previous system led to an influx of "bogus" refugees which swamped the system, thereby creating a backlog which in the end favoured "bogus" refugees and penalized "real" refugees.

However, Matas not only examines Canada's refugee policy, but that of Western Europeannationsand the United States as well. He looks at policies that not only prevented asylum seckers from landing on Western soil, but also at the conditions which arecreated and fostered by Western governments that discriminate against refugee claimants once they are in countries of asylum. For example, he notes that in many Western states refugees are prevented from seeking employment, and enroling in schools. In somestates, refugeeclaimants are held in detention centres until their status is resolved. In fact, he points out that "refugees are made to lead such miserable lives in the country of asylum that they are deterred even from seeking protection...refugee claimants are made to suffer, not just by circumstance, but by design." [Matas 1989:p 63-64]. Consequently, due to these types of conditions in some asylum countries, refugees are forced to leave in search of a new asylum country, hence explaining the landing of Tamils and later Slkhs off of Canadn's east coast in 1986 and 1987 respectively. This he points out creates an uneven burden on states with a lese restrictive policy.

Clouing the Doors also provides a brief history of the evolution of refugee protection and the creation of the United Nations High Commission on Refugees (UNHCR). In this way he attempts to show how the West has used refugee protection policy, on the one hand, to embarrass communist regimes, while on the other, refusing to recognize legitimate refugees from countries that havedismal human rights records because of their anti-communist/pro-western stance. This he maintains, points to the fact that refugee policy in Western Europe, the United States and Canada are lopsided. Consequently, legitimate refugeessuffer.

In concluding, therefore, it must be noted that Closing the Doors is an important addition to the literature on refugee studies. Matas has not only examined the Weat's refugee policy, but has been able to point out the hypocrisy that exista; what states preach (in terms of refugee protection) and what they actually do are very different. $\square$

\section{REFUGEES IN EUROPE}

By Dr. Daniele Joly (CREE, University of Warwick) with additional material by Clive Nettleton (formerly Head of Information, Refugee Council). Published on 1 October 1990.

Burope's fildden Fiuman Rights Abuse

At a time when the human rights record of most Buropean states is improving, little attention is paid to the plight of the growing number of asylumseekers who flee to Europe to seek refuge from torture and persecution. In 1972 there were 13,000 asylum-seekers; by 1988 the numbers had fisen to 232,000 .

New restrictions attempted to keep the refugees out. Visas are imposed, airlines are fined, asylum-seekers are detained - In pricon, on shipe, in tent cities akin to shanty towns - or forcibly deported. Even the Tucky ones must wait months or years for a decision on their status.

Refugees in Burope, a major new report from the London-based Minority Roghts Group, exposes the conditions awaiting asylum-aekersand refugees in Burope - the hidden alde of the humm rights agenda. Minority Rights Group is calling for a fundamental review of Burope's policies and practices on refugees.

Refugees in Europe has been released to coincide with the meeting in Geneva of the UNHCR Bxecutive Committee from 1 October, 1990. WRG presented each member of the Brecutive Committee with a copy of the report.

\section{CIDA provides \$2.5 Mullons in} Add for Jordan

Canada provided $\$ 2.5$ million in emergency assistance for displaced persons from Iraq and Kuwait in jordan.

The funds were distributed to International Organisation for Migration COM, League of Red Cross and Red Crescent Societies (LCRS), and to UNICER.

Canada was the first country to commit \$1 million to IOM to assist the tranoportation and evacuation of the dilopinced persons $\square$ 


\section{CONFERENCE OF THE CANADIAN ASSOCIATION OF AFRICAN STUDIES}

May 16 - 18, 1991

\section{York University, Toronto}

The general theme of the conference will be:

\section{AFRICA IN THE 1990s: DEVELOPMENT WITH DEMOCRACY}

There will be a stream of consecutive sessions on refugee related isoues.

The following topics have been suggested: Human Rights in Africa; Conflicts between Asylum and Majoritarian Democracy; Development Asoistance Related to National and Refugee Self Determination; Neo-Colonialism: International Agencies and NGOs working with Refugees; and Repatriation of Refugees and its effects on Democracy.

All proposals must be accompanied by an abstract of 150 . 120 words. A final call for papers will be isoued in December 1990 .

Please send all abstracts, enquiries and suggestions to Ogenga Otunnu or Prof. Howard Adelman, Centre for Refugee Studies, York University, $\mathbf{4 0 0}$ Keele St., North York, Ontario, Canada M3J 1P3

Please remember
to renew
your subscription for
Refuge.

\section{INTERNATIONAL CONFERENCE ON MIGRATION}

\author{
FEBRUARY 7 - 9,1990 - SINGAPORE
}

\section{CALL FOR PAPERS}

Rapid economic growth and changing political and social conditions in the AsiaPacificregion have fostered new migration patterns which are likely to persist into the 1990s. New Patterns of migration can be discerned at the intra-regional level, e.g. within ASEAN, and at the inter-regional level, e.g. from Southeast Asia and East Asia to North America and Australia.

The conference provides an opportunity to bring together scholars, practioners, and policy-makers from the Asia-Pacific area to analyze various dimensions of the phenomenon as manifested in the 1980 s and to explore likely future trends and patterns of migration.

The themes of the Conference will be:

1. Overview of migration patterns in the region (Asean, SB Asia, Bast Asia).

2. Theorles and concepts of migration in the literature.

3. Overview and evaluation of methodological issues in migration research.

4. Types and patterns of migration: voluntary migration, forced migration, internal migration, return migration and illegal migration.

5. Migration policy: theoretical, moral, practical and legal issues.

6. Country reports (Asean, SB Asia, East Asia).

7. Settlement and adaptation of immigrants.

Papers are invited on any of these themes. The Organiaing Committee regrets that it is unable to provide financial asdistance to paper writers. Abstracts of papers should be submitted by September 30, 1990 and completed papers by December 31, 1990 to:
Dr. Chew Soon Beng
Chairman, Organizing Committee
Centre for Advanced Studies
Faculty of Arts and Social Sciences
National University of Singapore
10 Kent Ridge Crescent
Singapore 0511, Republic of Singapore

The Conference will comprise plenary sessions and simultaneous workshope. The Organizing Committee will allocate conference papers into plenary session or workshop for presentation at its discretion. All enquiries are welcome.

Registration fee per person is $\$ \$ 250$.

Hotel accommodation at RELC (Singapore) is $\$ 110 /$ net per guestroom (single/ twin) per day. 


\section{ANNOUNCEMENT \\ International Research and Advisory Panol on \\ REFUGEES AND OTHER DISPLACED PERSONS \\ Socond Annual Meeting • Oxford, U.K. \\ 2 - 5 January 1991}

In January 1990, the Refugee Studies Programme, University of Oxford, convened the first meeting of its International Research and Advisory Panel. This meeting recommended that an independent body be established to provide a forum for the discussion and identification of issues related to research on refugees. It was agreed to meet annually for three full days in the first week of January. Five governments - Denmark, the Netherlands, Norway, Sweden and the UK, funded their own national representative and oneother fromadeveloping country.

The report of this meeting and terms of reference for the IRAP are available on request from the $R S P$.

The meeting is scheduled for 1991 with arrival from lunchtime, 2 January, and departure after breakfast on the 6th, requiring participants to spend four nights in Oxford. The venue for this meeting is Lady Margaret Hall, an Oxford college situated on the Cherwell Rtver. Rooms are en-suite and the cost of full board for the period is $\mathbf{2 0 0}$ pounds.

The deadline for registration is 1 October, 1990. A non-refundable deposit of 50 pounds is required with thecompleted registration form. Participation will be limited to sixty persons.

INVITATION AND CALL FOR PAPERS

International Symposium

RESPONDING TO THE NUTRITIONAL CRISIS OF REFUGEES: THE NEED FOR NEW APPROACHES

17th - 20th March 1991

Plense contact:

The Sympostum Coordinator

Refugee studies Programme

Queen Blizabeth House

University of Oxford

21, St. Giles

Oxford, OX1 3LA

U.K.
RECENT PUBLICATIONS

Public Policy and

Indochinese Refugees

by Robert Wayne Eisenhart

U.M.L. Dissertation Information

Service - University Microfilms

International, Ann Arbor, Michigan, 1990

The Northern Route:

An Ethnography of Refugee

Experience

by Lisa Gilad

Institute of Social and Economic Research, Memorial University of Newfoundland, 1990.

ISBN 0-919666-68-X

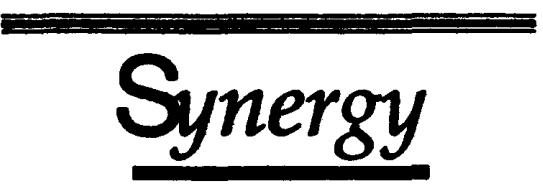

A quarterly newsletter about Canadian involvement in international health, published in English and French.

If you are interestedinhealth-related development isoures and work in an sodemic institution, non-governmental organization, in government, or the private sector, symersy will keep you informed with:

- News

- Commentary

- Events

- Advertioing

To add your name to the malling list, or to requect more information, contact:

\section{Syners}

Aceociation of Universities and

Colleges of Conada

151 Slater Street, Ottawn,

Ontario

Canad KIP SNI

Tel: (613) 563-1236

Fax: (613) 563-9745 


\section{VINCENT KELLY AWARD}

he Vincent Kelly Award is ted each year by the Centre for e Studies of York University to lians for outstanding work on $f$ of refugees.

The captain, officers and crew of MCS Provider not only rescued amese boat people, not only ded all Canadians of over a decade nmitment to resettling the Boat I In Canada (which helped the tian people win the Nansen 1), but they performed their nitarian rescue with grace, lity and a truegenerosity of spirit. he Centre of Refugee Studies of University, on behalf of all ians, wishes to announce at this lat at its annual dinner this Winter, incent Kelly Award will be ted to Captain Kenneth Scotten alf of the officers and crew of the iProvider.

\section{NNOUNCEMENT}

\section{NNUAL DINNER}

e Centre for Refugee Studies dinner will be held on March 7, 7500 p.m. at the International ant, 21-229 Dundas St. West, $3 r$ and will feature a 10-course

mier Bob Rae has been invited nt the Vincent Kelly Award to Kenneth Scottenon on behalf of cers and crew of the HMCS :

e captain, officers and crew of SProvider rescued Vietnamese ple in the Spring of 1990.

iets: $\$ 60$

secontact the Centrefor Refugee or more information.

\section{NEW PUBLICATIONS}

THE INTERNATIONAL REFUGEE CRISIS

Edited by Howard Adelman

Centre for Refugee Studies, York University, North York, Ontario, July 1990.

The price is $\$ 10$ in Canada or U.S.\$15 overseas. (postage included)

The publication summerizes the project sessions of the multi-disciplinary exchage. Key issues, concepts, policy development and cooperation are explored and synthesized.

\section{Satisfaction with Social Conditions in Canada: A Longitudinal Study of Latin Americans and Three Immigrant Groups (1969-74) By Fermando G Mate}

Doctoral thesis (1987) on immigrant working and living conditions in Canada.

The price is $\$ 25$ in Canada and U.S.\$30 overseas. (postage included)

Both publications are available from:

Centre for Refugee Studies

York University

Administrative Studies Building, Suite 234

4700 Keele Street

North York, Ontario,

Canada M3J 1P3.

\section{Now Available \\ from the National Film Board of Canada
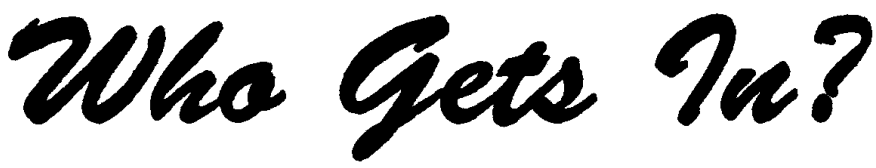

An unprecedented front-line view of the Canadian immigration process in action. This documentary, shot in Canada, Africa and Hong Kong raising questions about the nature of Canadian immigration policy.

National Film Board of Canada

Head Office:

Box 6100, Station A, Montreal, Quebe H3C 3H5

Tel: (514) 283-9411 • Fax: 496-1895 


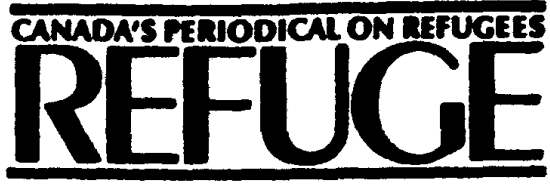

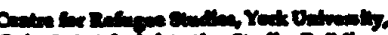

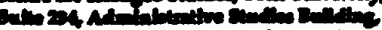

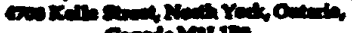

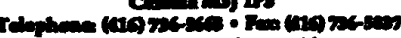

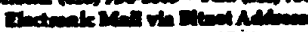
nirucasorivia

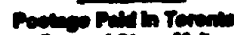

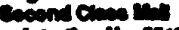

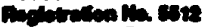

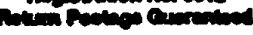

\section{UNHCR CELEBRATES 40TH ANNIVERSARY OF ITS CREATION Toronto - October 2, 1990}

Canadian events marking the 40th anniversary of the creation of the office of the united Nations high Commissioner for Refugees (UNHCR) and the signing of the United Nations Convention on the Status of Refugees kick off at 7:00 p.m. on Sunday, December 2, in Toronto.

"Over the past 40 years, the UNHCR has helped find solutions for more than 26 million refugees," said Stephen Lewis, former Canadian Ambassador to the United Nations. "We have something both to commemorate and continue which requires the efforts of the entire international community. This event will help to highlight the achievements and the needs".

Roy Thomson Hall will be the site of a concert of classicalmusicand song, featuring world-renowned opera singers Barbara Hendricks and Gino Quilico, accompanied by the Toronto Symphony Orchestra. Steven Mercurio, of the New York Metropolitan Opera, will conduct the Toronto Symphony. Ms. Hendricks, Mr. Quilico and Mr. Mercurio are donating their services for the occasion, which not only celebrates UNHCR's work for refugees over 40 years, but also Canada's role in helping refugees, as acknowledged by the award of the NansenMedal in 1986 , to the people of Canada.

At the same time, the concert will celebrate the contributions refugees have made to this country. An exhibit in the lobby of Roy Thomson Hall will feature artistic works by Canadians who came to the country as refugees.

The UNHCR was created by the United Nations General Assembly and began its operations on January 1, 1951. Its purposes are to offer legal protection for refugees and to seekdurablesolutions for them. UNHCR is headquartered in Geneva, Switzerland, is represented in more than 80 countries and has a staff of nearly 2,000 assisting over 14 million refugees worldwide.

Tickets are available from Roy Thomson Hall Box Office at prices ranging from \$15-\$45. A special $\$ 100$ ticket includes a reception with theartists. Any profits will go to UNCHR programmes overseas.

For $\$ 100$ tickets and information about sponsorship opportunities, please call Mrs. James Robertson (Peggy)at967-2797 orMrs. William Forbes (Sybil) 485-2198. 